\title{
Leaving a Legacy as a Medical Student
}

\author{
Al-Sukaini, A; Qureshi, M; Suker, F
}

What do you want to achieve by the end of your medical degree? Do you simply want to complete your life as a medical student unscathed and reach the finishing line with a degree? Or do you want to leave a mark in the pages of history before you have even earned your first pay cheque as a medical professional?

Examination of history reveals that medical students have been influential in contributing to medical discoveries and developments. Insulin, heparin, ether anaesthesia and the sinoatrial node are but a mere few of the major findings made by individuals who were once in our very position - as medical students - that have had an enormous impact in the field of medicine. Never feel unimportant or that you are a hindrance to doctors as a medical student due to your inexperience. The five inspirational figures that we will discuss in this piece not only left their mark, but they made such an impact during their life as a medical student, that their names will forever remain etched in medicine until the end of time.

During a summer vacation in the year 1867, a young medical student by the name of Paul Langerhans, rather than spending his time in the sun, decided to devote his hours in the laboratory; studying the cell types within the pancreas. A year earlier, he had already displayed his evident talent by staining a sample of human skin with gold chloride and describing the dendritic cells which to this day, bear his name. At this juncture in history, the pancreas had been considered a salivary gland of some type. After many painstaking hours, Langerhans identified a new cell which scarcely corresponded to the concept of a salivary gland. (2) He described a "small, irregularly polygonal structure. It's cytoplasm is brilliant and free of any granules. Its nucleus distinct, round and moderate size... these cells lie together generally in considerable numbers, diffusely scattered in the substance of the gland".(1) Langerhans developed a Berlin blue and glycerine mixture for retrograde injection into the pancreatic duct and this exhibited the widely branching collecting system. Intriguingly, his newly discovered cells showed no apparent relation to the duct system. As a result, Langerhans concluded his thesis "I cannot in any way put forth the conclusive results of a completed investigation. I can at most describe a few isolated observations which suggest a much more complicated structure of the pancreas than hitherto accepted." (I) Langerhans completed his work within six months - the length of a modern medical school research project. It was five years later in fact, that Langerhans' name was attached to these "magic islands" by Edouard Laguesse. The islands were soon described to have an internal secretory activity and these were the first steps in a series of events which led to the discovery of lifesustaining insulin in 1922. (2)

The series of events mentioned that culminated in the discovery of insulin had a degree of symmetry in that the chain began with a medical student (Langerhans) and ended with another medical student by the name of Charles Herbert Best. This student's contribution to medicine brought him within inches of a Nobel Prize. Sir Frederick Banting was the catalyst behind this project. In 1921 he approached John Macleod, a professor of Physiology at the University of Toronto, with the proposal of finding a cure for diabetes mellitus. ${ }^{(3)}$ The duo recruited Best and a technician - James Collip - to assist with the venture. After a year of tireless work, they discovered "Isletin" (insulin). By late 1921, these academics were able to show the efficacy of insulin in treating canine diabetes. Subsequently, in February 1922, they administered the first insulin injection to successfully treat a fourteen year old diabetic.(4) The Nobel committee awarded the prize only to Banting and Macleod. Aggravated, Banting shared half of his prize money with Best and Macleod half of his with Collip. Later in 1929 Best succeeded Macleod as professor in physiology, (3)

Niels Stensen (|638-|686) was a multi-talented Danish anatomist, a theologist and a natural scientist fluent in German, Dutch, French, Italian and Arabic to name but a few languages. (6) Throughout the course of his career, he made a catalogue of brilliant discoveries. The first of these took place on $7^{\text {th }}$ April |66| as a medical student. Stensen had purchased a sheep's head for dissection and analysis. He was working on the veins of the face when to his surprise, the scalpel slipped through a "cavity" and struck the teeth. The cavity was the parotid duct and is still referred to in some modern textbooks as Stensen's duct. Within a short span of time, he went on to identify the ducts of the lacrimal, sublingual and buccal glands, thus enhancing his fast-growing reputation in his early student years. ${ }^{(7)}$ Having studied anatomy under Professor Gerhard Blaes (Blasius), he later described the Tetralogy of Fallot, a congenital cardiac anomaly. ${ }^{(5)}$ Stensen's work is a prime example of how a keen thirst for knowledge, in this case a knowledge of anatomy, can reap unexpected rewards. ${ }^{(6)}$

Petrus Camper ( 1722 - 1789) was a Dutch physician and anatomist. He had an illustrious career with many terms named after him including the most prominent Camper's fascia. ${ }^{(8)}$ However, his first significant contribution to medical research came as a student in the field of micro anatomy, where he established that the lens of the eye is made up of fibres. This had previously been assumed by the great natural scientist and microscopist Antonie van Leeuwenhoek (| 632- | 723). ${ }^{(9)}$ This case exhibits an evidently keen and enthusiastic student who had the presence of mind to build and expand upon the foundations of work which had been postulated in a previous generation.

A more contemporary example is that of lan McManus, who in 1973 wrote his first paper on laterality, an area in which he is now a leading world expert. As a medical student, he cited research showing that the right testicle tends to be higher in right-handed men, whereas the opposite is true in lefthanders. McManus examined 107 antique sculptures where he discovered that in the majority of the cases the right testicle was higher. ${ }^{(10)}$ McManus displayed that sharp observation, no matter how bizarre, can prove to be a very precious asset in a medical student's repertoire.

The pioneering contributions of the aforementioned quintet of individuals, not to mention countless others, serve as a powerful reminder of what can be achieved as a medical 
student with a drop of talent and oceans of dedication. These students left their legacies behind along with their shoes which are waiting to be filled by those of us who are willing. Our medical student experiences and achievements can act as a huge catapult, to propel us into the stratosphere of success.

With medical schools across the world increasingly integrating research projects into their curricula, it is a golden opportunity for us to both stimulate our intellectual appetites and to contribute towards ongoing medical and professional development. In a conventional five year journey as a medical student we have I,825 days, 43,800 hours, 2,628,000 minutes and countless moments in which to strive to create a legacy. With purposeful intentions, strong determination and a desire to succeed, that moment could be within touching distance. Let us reach out and seize it.

\section{REFERENCES}

I. Morrison, $\mathrm{H}_{\text {.: }}$ Contributions to the microscopic anatomy of the pancreas by Paul Langerhans. Bull. Inst. Hist. Med., 5:259265,1937

2. Lev E, Ohry-Kossoy K, Ohry A. Langerhans in the Middle East: More about the discoverer of the pancreatic islets. Vesalius, 2003; 9:19-21.

3. Thomas H. Jukes Charles Herbert Best (I 899-1978). A Biographical Sketch. [cited 2012 April 9] http://jn.nutrition. org/ content// |0////9.full.pdf

4. F. G. Banting, C. H. Best, "Pancreatic Extracts in the treatment of Diabetes Mellitus" Can Med Assoc J. Mar | 922; | 2(3): | 4 |- | 46

5. Tubbs RS, Gianaris N, Shoja MM, Loukas M, Cohen Gadol AA. "The heart is simply a muscle" and first description of the tetralogy of "Fallot". Early contributions to cardiac anatomy and pathology by bishop and anatomist Niels Stensen ( 638- | 686), Int J Cardiol. 20 I2; I 54(3): 31 2-5.

6. Perrini P, Lanzino G, Parenti GF. Niels Stensen (| 638-| 686): scientist, neuro-anatomist, and saint. Neurosurgery, 2010 Jul; 67(1): 3-9.

7. Young, J. R: An experimental enquiry into the principles of nutrition and the digestive process. M.D. thesis, University of Pennsylvania.

8. Mccullough LB, John Gregory and the invention of professional medical ethic and the profession of medicine. Kluwer Academic Publishers, Dordrecht, Boston, London, vol. 56 in the series of Philosophy \& Medicine, 1996.

9. Garrison $\mathrm{FH}$, an introduction to the history of medicine, Saunders, Philadelphia, 1924 p. 838.

10. Brown C. Ignobel ( I): dressing for success. CMAJ. 2002 Dec 10; $167(12): 1340$. 